\title{
EFEK MODEL PEMBELAJARAN MIND MAPPING UNTUK MENINGKATKAN HASIL BELAJAR SISWA PADA MATERI POKOK GELOMBANG ELEKTROMAGNETIK
}

\author{
Ika Trisni Simangunsong \\ Dosen Jurusan Pendidikan Fisika Universitas Darma Agung, Medan \\ Email : ikatrisnisimangunsong@gmail.com
}

Diterima 20 Juni 2017, disetujui untuk publikasi 15 Agustus 2017

\begin{abstract}
Abstrak Penelitian ini bertujuan untuk mengetahui efek model pembelajaran Mind Mapping terhadap hasil belajar siswa pada materi pokok gelombang elektromagnetik. Jenis penelitian ini adalah quasi eksperimen dengan populasi seluruh siswa kelas X SMA Swasta Raksana Medan yang terdiri dari 4 kelas. Pengambilan sampel dilakukan dengan cara cluster random sampling terpilih 2 kelas yaitu kelas X-2 sebagai kelas eksperimen dengan model pembelajaran Mind Mapping dan kelas X-1 siswa sebagai kelas kontrol dengan model pembelajaran langsung. Instrumen yang digunakan adalah tes hasil belajar dalam bentuk pilihan berganda berjumlah 20 soal dengan lima option yang terlebih dahulu diuji cobakan terhadap siswa di luar sampel yang sudah mempelajari materi ini untuk mengetahui validitas, reliabilitas, daya pembeda, dan tingkat kesukaran soal. Dari hasil penelitian diperoleh bahwa sampel berasal dari populasi yang homogen dan

Kata kunci: berdistribusi normal. Berdasarkan hasil uji statistik diperoleh ada efek yang Mind mapping, hasil signifikan model pembelajaran Mind Mapping terhadap hasil belajar siswa pada materi pokok gelombang elektromagnetik di Kelas X Semester II SMA Swasta Raksana Medan.

belajar, gelombang elektromagnetik.
\end{abstract}

\section{Pendahuluan}

Kemajuan suatu bangsa sangat ditentukan oleh kualitas suatu sumber daya manusia, dimana kualitas sumber daya manusia tersebut bergantung pada pendidikan. Pendidikan memegang peranan yang sangat penting dalam pengembangan semua potensi, kecakapan, serta karakteristik sumber daya manusia ke arah positif, baik bagi dirinya maupun bagi lingkungannya. Oleh karena itu pendidikan harus sejalan dengan perubahan budaya kehidupan, ilmu pengetahuan dan teknologi. Undang-undang No. 20 Tahun 2003 Bab II Pasal 3 menyatakan Pendidikan Nasional berfungsi untuk mengembangkan kemampuan dan membentuk watak serta peradaban bangsa yang bermanfaat dalam rangka mencerdaskan kehidupan. Selanjutnya dalam pasal 3 juga dikatakan tujuan pendidikan nasional untuk berkembangnya potensi peserta didik agar menjadi manusia yang beriman dan bertaqwa kepada Tuhan Yang Maha Esa, berakhlak mulia, sehat, berilmu, cakap, kreatif, mandiri dan menjadi warga negara yang demokratis serta bertanggung jawab.

Fisika adalah ilmu yang mempelajari tentang alam semesta, fenomena alam dan mekanisme yang terjadi di dalamnya. Lebih sederhananya dapat dikatakan bahwa fisika erat kaitannya dengan kehidupan seharihari. Apa yang dialami, apa yang dilakukan, kenapa hal itu terjadi, dan mengapa demikian. Fisika berhubungan dengan pengamatan, pemahaman, dan peramalan fenomena alam, termasuk sifat-sifat sistem buatan manusia. Dalam pengajaran saat ini tampak sekali dilewatinya proses penemuan 
rumus dan buku pelajaran fisika tak ubahnya ringkasan pelajaran yang tak merinci sebuah proses. Padahal, proses ini yang seharusnya menjadi butir penting agar siswa nantinya memiliki hasil belajar yang tinggi dan cerdas dalam sekolahnya. Namun kenyataannya kemampuan siswa dalam fisika rendah. Hal ini sesuai dengan data dari Dinas Pendidikan kota Medan tentang hasil UAN siswa tingkat SMA tahun pelajaran 2013/2014, menunjukkan bahwa nilai ratarata UAN Fisika adalah 7,52. Nilai ini termasuk rendah bila dibandingkan dengan nilai Bahasa Indonesia 7,65; Matematika 8,45; Kimia 8,47, dan Biologi 7,98.

Hasil wawancara yang dilakukan kepada guru fisika kelas $X$ di SMA Swasta Raksana Medan, secara umum hasil belajar fisika siswa masih rendah. Hasil belajar siswa masih rendah dikarenakan siswa sulit untuk mengingat kembali pelajaran yang sudah dipelajari karena siswa mencatat semua apa yang dijelaskan oleh guru, siswa sering menghafal rumus-rumus bukan pemahaman konsepnya. Ketika peneliti melakukan observasi di salah satu kelas $X$ pada saat observasi awal hanya 40\% (16 orang) siswa mengatakan belajar fisika itu menyenangkan, $60 \%$ (24 orang) mengatakan belajar fisika itu rumit, sulit mengingat rumus-rumus, guru tidak membuat bagianbagian penting pelajaran pada saat pembelajaran berlangsung, guru hanya menjelaskan teori (berpusat pada guru) alatalat laboratorium kurang dimanfaatkan, sehingga siswa tidak dapat langsung mempraktekkannya, hal itu menjadi terkesan monoton dan tidak menarik.

Penelitian ini menawarkan model pembelajaran Mind Mapping untuk dapat meningkatkan hasil belajar siswa. Dengan menggunakan model pembelajaran Mind Mapping, diharapkan permasalahan tersebut dapat teratasi. Mind Mapping melibatkan kombinasi unik dari citra, warna dan pengaturan visual spasial yang terbukti secara signifikan meningkatkan daya ingat. Mind Mapping boleh dikatakan sebuah peta rute yang ingatan dan diarahkan untuk memadukan mengembangkan kerja otak yang terdapat di dalam diri seseorang. Melalui model pembelajaran ini siswa diharapkan menjadi kreatif, dapat mengingat informasi lebih mudah.

Menurut Rappel (2013) terdapat pengaruh yang signifikan terhadap hasil belajar fisika siswa dengan menggunakan peta pikiran (mind mapping). Risnawati, dkk (2015) menemukan hasil penelitian (1) nilai rata-rata siswa meningkat dari $94,68 \%$ menjadi $96,09 \%$ (2) jumlah siswa yang mencapai nilai KKM meningkat dari 58,06\% menjadi 83,87\%. Heri Riswanto (2015) dengan judul "Upaya Meningkatkan Hasil Belajar Ilmu Pengetahuan Alam (IPA) Dengan Metode Pembelajaran Mind Mapping". Hasil penelitian menunjukkan bahwa: nilai rata-rata siswa di kelas eksperimen setelah proses belajar mengajar selesai meningkat menjadi 81,57 sedangkan di kelas kontrol 71,10".

Dari ketiga hasil penelitian di atas model pembelajaran Mind Mapping dapat meningkatkan daya ingat dan hasil belajar siswa. Oleh karena itu penelitian ini bertujuan untuk mengetahui efek Model Pembelajaran Mind Mapping Untuk Meningkatkan Hasil Belajar Siswa Pada Materi Pokok Gelombang Elektromagnetik.

\section{Metode Penelitian}

Penelitian ini adalah penelitian quasi eksperimen. Populasi penelitian ini adalah seluruh siswa kelas X Semester II SMA Swasta Raksana Medan T.A 2015/2016 yang terdiri dari 4 kelas. Sampel penelitian dilakukan dengan cara tehnik acak kelas (cluster random sampling) sebanyak dua kelas. Dimana kelas pertama dijadikan kelas eksperimen (kelas X-2) dengan menggunakan Mind Mapping dan kelas kedua dijadikan kelas kontrol (kelas X-1) dengan pembelajaran konvensional, dengan masing-masing kelas berjumlah 40 orang siswa. 
Peneliti melakukan tes untuk mengetahui hasil belajar fisika siswa pada kedua kelas sebelum dan sesudah diberikan perlakuan. Desain penelitian yang digunakan desain two group pretest-posttest design.

Data yang diperoleh ditabulasikan kemudian dicari rata-ratanya. Sebelum dilakukan perlakuan, terlebih dahulu ditentukan nilai masing-masing kelompok sampel lalu dilakukan pengolahan data dengan langkah-langkah sebagai berikut yakni : menghitung nilai rata-rata dan simpangan baku, uji normalitas menggunakan uji Lilliefors, uji homogenitas menggunakan uji $\mathrm{F}$, pengujian kesamaan rata-rata pretes menggunakan uji t dua pihak dan pengujian hipotesis menggunakan uji $t$ satu pihak pada data postes.

\section{Hasil Penelitian dan Pembahasan}

Instrumen yang digunakan adalah tes hasil belajar dalam bentuk pilihan berganda berjumlah 20 soal dengan lima option yang terlebih dahulu diuji cobakan terhadap siswa di luar sampel yang sudah mempelajari materi ini untuk mengetahui validitas, reliabilitas, daya pembeda, dan tingkat kesukaran soal.

Sebelum melakukan proses pembelajaran terlebih dahulu dilakukan pretes untuk mengetahui kemampuan awal siswa di kelas eksperimen dan di kelas kontrol. Dari hasil pretes diperoleh nilai ratarata pretes kelas eksperimen yaitu 36,25 dengan standar deviasi 13,48 sedangkan nilai rata-rata pretes kelas kontrol yaitu 36 dengan standar deviasi 12,25. Setelah dilakukan uji persyartan data yaitu uji normalitas dan uji homogenitas, maka dilakukan uji hipotesis dengan uji $t$ dua pihak. Hasil uji $\mathrm{t}$ dua pihak diperoleh thitung $<$ tabel yaitu 0,088 < 1,994, artinya bahwa kemampuan awal kedua sampel adalah sama. Gambaran hasil pretes dapat dilihat sepeti pada diagram batang pada Gambar 1 .

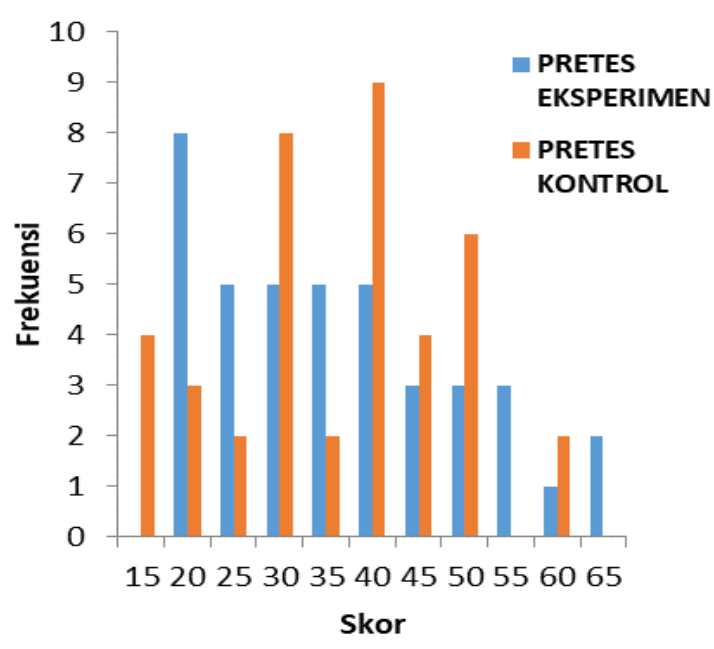

Gambar 1. Diagram Batang Data Pretes Kelas Eksperimen dan Kelas Kontrol

Kemudian peneliti melakukan proses pembelajaran yaitu pada kelas eksperimen diajar dengan menggunakan model pembelajaran Mind Mapping, pada kelas kontrol diajar dengan menggunakan model pembelajaran Langsung. Setelah diberikan perlakuan yang berbeda diperoleh nilai ratarata postes kelas eksperimen yaitu 73,75 dengan standar deviasi 12,39 sedangkan nilai rata-rata postes untuk kelas kontrol yaitu 66 dengan standar deviasi 11,83.

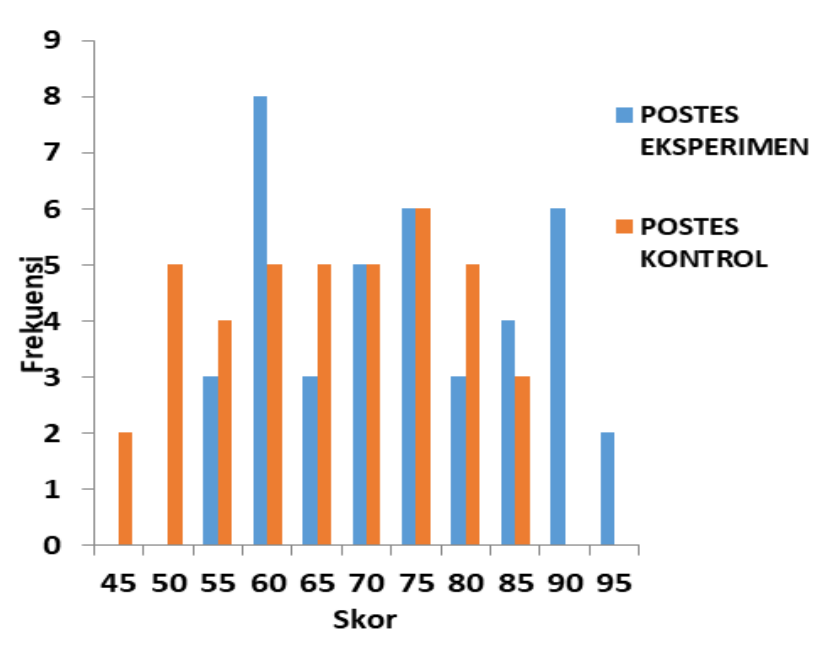

Gambar 2. Diagram Batang Data Postes Kelas Eksperimen dan Kelas Kontrol 
Dari rata-rata nilai postes terlihat bahwa hasil belajar siswa meningkat. Setelah dilakukan uji hipotesis thitung $>$ tabel yaitu 2,913>1,667 maka dapat disimpulkan bahwa ada efek yang signifikan model pembelajaran Mind Mapping terhadap hasil belajar siswa. Hal ini juga didukung dengan hasil penelitian terdahulu, yang menyatakan bahwa ada pengaruh yang signifikan dari model pembelajaran Mind Mapping terhadap hasil belajar siswa.

Selama pelaksanaan penelitian ini diperoleh bahwa model pembelajaran Mind Mapping lebih menguntungkan karena model ini memang didesain untuk membuat siswa lebih aktif (student centered learning) dalam menggali, mencatat kreatif, menganalisis, mengevaluasi konsep terhadap materi pelajaran yang sedang dipelajari. Model pembelajaran Mind Mapping merupakan model yang efisien untuk mempresentasikan informasi yang telah terorganisir dari suatu topik yang luas menjadi topik yang lebih mudah dipahami untuk setiap tingkatan perkembangan konsep, hal ini juga didukung karena model pembelajaran Mind Mapping lebih mendekatkan siswa kepada kehidupan yang lebih nyata dan dekat dalam kehidupan sehari-hari.

Walaupun penggunaan model pembelajaran Mind Mapping dapat meningkatkan hasil belajar, akan tetapi selama pembelajaran masih ada kendala yang dihadapi, yaitu waktu yang diperlukan untuk tiap-tiap fase kurang sesuai dengan skenario waktu yang telah direncanakan dalam Rencana Pelakasanaan Pembelajaran (RPP). Oleh karena itu, untuk peneliti selanjutnya supaya memberikan pengawasan yang lebih dengan dibantu oleh salah satu guru di sekolah yang menjadi tempat penelitian dan waktu yang direncanakan dalam RPP supaya lebih diperhatikan khususnya waktu dalam kegiatan memeriksa buku catatan karena siswa-siswi SMA pada umumnya jarang mencatat apa yang sudah dipelajari, keterbatasan peneliti dalam mengalokasikan waktu pada saat siswa mengajukan hasil diskusi mereka sehingga tidak semua kelompok dapat menyajikan hasil diskusi mereka. Selain waktu masalah yang dihadapi peneliti adalah masih ada sebagian siswa yang kurang aktif dalam proses pembelajaran, ada beberapa siswa yang lebih memilih duduk diam dan menunggu hasil yang diperoleh oleh temannya.

Untuk melihat persentase peningkatan hasil belajar siswa digunakan rumus:

$$
\begin{aligned}
& \% \quad \text { Efek peningkatan hasil } \\
& \text { belajar }=\frac{\bar{x} \text { eks }-\bar{x} \text { kont }}{\bar{x} \text { kont }} \times 100 \% \\
& =\frac{7975-66}{66} x 100 \% \\
& =11,7 \%
\end{aligned}
$$

Berdasarkan perhitungan persentase hasil belajar siswa di atas maka diperoleh peningkatan sebesar $11,7 \%$, sehingga dapat disimpulkan bahwa ada efek yang signifikan model pembelajaran Mind Mapping terhadap hasil belajar Siswa pada materi pokok Gelombang Elektromagnetik di kelas X semester II SMA Swasta Raksana Medan. Mind Mapping ini membuat siswa lebih terarah dan focus terhadap apa yang dipelajari, sehingga mereka berusaha mencari tahu makna dari topik-topik yang dipelajari.

\section{Simpulan dan Saran}

Hasil belajar siswa dengan model pembelajaran Mind Mapping sebelum diberikan perlakuan rata-rata pretes sebesar 36,25 dan setelah diberikan perlakuan ratarata postes siswa sebesar 73,75. Hasil belajar siswa yang menggunakan pembelajaran konvensional sebelum diberikan perlakuan rata-rata pretes sebesar 36 dan setelah diberikan perlakuan rata-rata postes siswa sebesar 66. Kepada guru yang berencana menggunakan model pembelajaran ini, pada saat melakukan percobaan waktu banyak terbuang karena siswa belum memahami langkah-langkah percobaan. Diharapkan 
Efek Model Pembelajaran Mind Mapping Untuk Meningkatkan Hasil Belajar Siswa Pada Materi Pokok Gelombang Elektromagnetik

guru harus terlebih dahulu mendemonstrasikan langkah-langkah pembuatan mind mapping, agar siswa paham. Sebelum model ini diterapkan, sebaiknya memahami terlebih dahulu pembelajaran mind mapping sehingga model pembelajaran ini dapat diterapkan dengan benar, agar pembelajaran berjalan lebih kondusif dan sesuai dengan rencana pembelajaran yang sudah dirancang.

\section{Daftar Pustaka}

Istarani. 2012. 58 Model Pembelajaran Inovatif, Media Persada, Medan,

Kurniasih, Imas dan Sani, B. 2015. Ragam Pengembangan Model Pembelajaran, Yogyakarta: Kata Pena.

Risnawati., Rachmatiah., Wardani, Nurul Kusuma., Subaer. 2015, Penerapan Pembelajaran Aktif Berbasis Mind Mapping untuk Meningkatkan Daya Ingat Siswa dan Hasil Belajar Fisika Untuk Suhu dan Pemuaian pada Siswa
Kelas VII SMP Negeri 24 Makassar, Prosiding Pertemuan Ilmiah XXIX HFI Jateng \& DIY, ISSN : 0853-0823

Riswanto, Heri. 2015, Upaya Meningkatkan Hasil Belajar Ilmu Pengetahuan Alam (IPA) Dengan Metode Pembelajaran Mind Mapping, Jurnal Formatif 5(2): 100-106, 2015, ISSN:2088-351X

Sadirman. 2009. Interaksi dan Motivasi Belajar Mengajar, Jakarta: Raja Grafindo Persada.

Sagala, S. 2009. Konsep dan Makna Pembelajaran, Bandung: Alfabeta.

Situmorang, Rappel. 2013. Pengaruh Metode Peta Pikiran Terhadap Hasil Belajar Siswa Pada Materi Suhu dan Kalor di SMA Negeri 2 Tebing Tinggi, Jurnal Penelitian Pendidikan, Vol. 19, (1), 19-27.

Sudjana., 2015, Metoda Statistika, Tarsito, Bandung. 